\title{
Internet Addiction Disorder and Its Pathogenicity to Psychological Distress and Depression among University Students: A Cross-Sectional Pilot Study in Bangladesh
}

\author{
Md. Sahab Uddin 1* , Abdullah Al Mamun', Mohammed Ashraful Iqbal'2, Md. Nasrullah', \\ Md. Asaduzzaman', Md. Shahid Sarwar', Md. Shah Amran4 \\ ${ }^{1}$ Department of Pharmacy, Southeast University, Dhaka, Bangladesh \\ ${ }^{2}$ Department of Chemistry, Fareast International University, Dhaka, Bangladesh \\ ${ }^{3}$ Department of Pharmacy, Noakhali Science and Technology University, Noakhali, Bangladesh \\ ${ }^{4}$ Department of Pharmaceutical Chemistry, Faculty of Pharmacy, University of Dhaka, Dhaka, Bangladesh \\ Email: "msu-neuropharma@hotmail.com, "msu_neuropharma@hotmail.com
}

Received 29 February 2016; accepted 12 July 2016; published 15 July 2016

Copyright (C) 2016 by authors and Scientific Research Publishing Inc.

This work is licensed under the Creative Commons Attribution International License (CC BY).

http://creativecommons.org/licenses/by/4.0/

c) (i) Open Access

\section{Abstract}

Worldwide Internet addiction is a newly emerging mental health and social issue among the youths causing neurological complications, psychological disturbances and social problems. Internet addicts make the Internet urgency more vital than family, friends and work. Several studies exposed that anxiety, backache, blurred vision, dry eyes, headache, sleep disturbance, depression, poor academic performance etc. are results of Internet addiction. Therefore, the objective of this study was to determine the Internet addiction as well as its psychological distress and depression among university undergraduate students of Bangladesh. The study was conducted among 475 students selected from five universities of Bangladesh from July 2015 to September 2015. The selected universities were Southeast University, University of South Asia, Primeasia University, Northern University Bangladesh and State University of Bangladesh. Each willing participants were subject of this study and they shared their opinion. The Young's Internet Addiction Test (IAT), the General Health Questionnaire (GHQ-12) and Beck Depression Inventory (BDI-2) were used to determine Internet addiction, psychological distress and depression respectively. Results revealed that the university students showed varying degrees of Internet addiction, psychological distress and depression with respect to sex, age, year of study and residential status. The data revealed that $47.7 \%(127)$ male and $44.5 \%$ (93) female students showed severe Internet addiction followed by $27.1 \%$ (72) male and $33.9 \%$ (71) female students showed moderate Internet addiction, while $20.7 \%$ (55) male and $7.7 \%$ (16) female students had mild Internet addiction. The lin-

\footnotetext{
${ }^{*}$ Corresponding author.
}

How to cite this paper: Uddin, Md. S. et al. (2016). Internet Addiction Disorder and Its Pathogenicity to Psychological Distress and Depression among University Students: A Cross-Sectional Pilot Study in Bangladesh. Psychology, 7, 1126-1137. 
kage between Internet addiction and sex was significant at $P<0.001$. Furthermore, $29.7 \%(79)$ male and 32.5\% (68) female students had psychological distress. Severe psychological depression was reported among $44.7 \%(119)$ male and $41.6 \%(87)$ female students. Equally year of study and residential status showed significant $(P<0.001 ; P<0.05, P<0.001)$ differences in Internet addiction and psychological depression. This study observed that university undergraduate students are at very close to the danger of Internet addiction and its pathological impact on psychological distress and depression. Therefore, the new generation is at great risk. However, without Internet scientific thinking is not possible. So only the rational use of the Internet can be fruitful in the long run.

\section{Keywords}

Internet Addiction, Pathogenicity, Psychological Distress, Psychological Depression, Rational Use

\section{Introduction}

Internet Addiction Disorder (IAD) is the extreme use of Internet that interferes with existence (Block, 2008). It is a multidimensional compulsive cognitive and behavior symptoms that completely dominates the addict's life (Pies, 2009). IAD is often comorbid with psychological disorders such as attention deficit hyperactivity disorder (ADHD) and depression (Kratzer \& Hegerl, 2008). Several studies show that within the first six months of using the Internet about $25 \%$ of users achieve Internet addiction criteria (Anonymous, 2016a). Worldwide the prevalence of IAD is $6 \%$ in which Middle East accounts for $10.9 \%$, North America accounts for $8 \%$, Asia accounts for 7.1\%, South and East Europe accounts for 6.1\%, Oceania accounts for 4.3\%, North and West Europe accounts for 2.6\% (Ryan, 2014; Woollaston, 2014). The variation of the prevalence of IAD may be because of the variation of assessment questionnaires, diagnostic criteria as well as selective use of participants. A study in the UK has been reported that the prevalence rates of the IAD as high as $18 \%$, whereas very low incidence, $0.8 \%$ has reported in the Italy (Poli \& Agrimi, 2012; Niemz, Griffiths, \& Banyard, 2006). According to the review of Weinstein and Lejoyeux the incidence rates of IAD in the United States and Europe have shown fluctuating between 1.5\% and 8.2\% (Weinstein \& Lejoyeux, 2010; Young \& de Abreu, 2011). Another review of more than 100 studies in China showed that over $12 \%$ of male and $5 \%$ of female students disclosed signs of Internet addiction (Wallace, 2014).

The causes of Internet addiction are not well known, but there are some known causes of Internet addiction that can vary by sex, age and personality. Social networking is one of the most common causes of Internet addiction (Kuss \& Griffiths, 2011). An Internet addicted person sometime feels web life just like a real one and develops highly emotional connections to online friends or even online dates. Online relationship via social network is another main source of Internet addiction (Leung \& Lee, 2012; Griffiths, 2013). A study has been reported that certain people may be predisposed to online addictions as like as one can be predisposed to an alcohol addiction (Echeburua \& de Corral, 2010). In fact, like drug addiction in Internet addiction, an analogous situation exists. The Internet similar to drugs in other addicted persons offers the euphoria feeling and addicts become reliant on this cyberspace in order to control the high feeling to normal. In addition to this when an Internet addict feels dazed, stressed, depressed and anxious, they use the Internet to search for comfort. Studies showed that people who are suffering from depression are more likely to develop Internet addiction (Ha et al., 2007; Young \& Rogers, 1998; Kim et al., 2006; Lee et al., 2001). Several studies suggest the presence of genetic predisposition to addictive behaviors (Eisen et al., 1998; Grant, Brewer, \& Potenza, 2006). As per to this concept genetic predisposition among people is due to lack of adequate number of dopamine receptors or have an insufficient amount of serotonin/dopamine, as a result they experience normal level of pleasure in events in which most people would find rewarding (Beard, 2005). In order to increase the level of pleasure these types of individuals are more disposed to search for such type of behaviors like Internet that make them reward, but simultaneously placing them at higher risk for addiction (Cash et al., 2012). The CIAR (Center for Internet Addiction Recovery) stated that Internet addicts suffer from emotional problems, including depression and anxietyassociated disorders and frequently use the fabulous world of the Internet to psychologically escape unpleasant feelings or stressful situations (Young, 2009; Anonymous, 2016b). In addition to this Internet addicts are also addicted to drugs, alcohol, tobacco, sex, chronic overeating etc. (Morris, 2009; Ho et al., 2014). Many scientists 
and researchers have claimed that the uncontrollable Internet users can generate morphological mutations in the structure of the brain. A study in Chinese college students exposed that use of computer for about 10 hrs a day and for 6 days a week, showed decreases in the dimensions of the dorsolateral prefrontal cortex, rostral anterior cingulate cortex, supplementary motor area and parts of the cerebellum compared to control students (Yuan et al., 2011). It has been hypothesized that these variations reveal learning-type cognitive optimizations for using computers more competently, but correspondingly diminished temporary memory and decision-making capabilities as well as increase the pleasure to remain online rather than the actual world (Mosher, 2011). Many researchers and clinicians have marked that a diversity of psychological disorders occurs together with IAD. There is controversy about which came first, the addiction or the co-occurring disorders (Ryan, 2014; Kratzer \& Hegerl, 2008). A previous study showed that depression, anxiety, hostility, interpersonal sensitivity and psychoticism were consequences of IAD (Ryan, 2014).

Researchers observed that most Internet users are young people, especially university undergraduates (Jones, 2002). Previous study exposed that Internet user is higher in younger than adult and mainly 19 to 24 years of age group are considered as a high risk group for Internet addiction (Koo \& Kwon, 2014). Another study exposed that university students are more at risk of becoming Internet addicts due to more free time, lack of monitoring on account of being away from parents and sometimes efforts to become away from arduous university routines (Soule, Shell, \& Kleen, 2003; Young \& Rogers, 1998; Kandell, 1998). As well as this Internet addiction is more predominant on university campuses because of laptops and computer labs are within easy proximity.

In Bangladesh the use of computer began in the 1960s and assumed widespread in the nineties (Zaman \& Rowshon, 2011). Like many developed and developing countries, the Internet in Bangladesh has perceived remarkable growth. However, only $0.1 \%$ of the population used the Internet in 2000 and it rises to $31.9 \%$ in 2015 (Anonymous, 2016b).

Previously, there was no study that showed the prevalence of IAD and its association with psychological problems in Bangladeshi students. Therefore the objective of this study was to analyze Internet addiction disorder and its co-relation with psychological distress and depression among undergraduate university students in Bangladesh.

\section{Materials and Methods}

\subsection{Study Site}

The study was conducted on undergraduate students selected from five universities of Dhaka, Bangladesh which were Southeast University, University of South Asia, Primeasia University, Northern University Bangladesh and State University of Bangladesh.

\subsection{Study Design and Data Collection}

This was a student based, cross-sectional study conducted among students selected from five universities in Dhaka, Bangladesh. The study was conducted between July 2015 to September 2015 and throughout this period a total of 475 students were selected. Information about sex, age, year of study, residential status and study relevant information were collected that is listed in Table 1.

\subsection{Internet Addiction Test}

In this study modified version of the Young's Internet addiction test was used (Young, 1998). It was a 20 item test with six point range from 0 to 5 . The response options were; 0 indicated did not apply, 1 indicate rarely, 2 indicated occasionally, 3 indicated frequently, 4 indicated often and 5 indicated always. The obtainable scores ranged from 0 to 100 in which higher total scores indicated excessive Internet uses. Scores ranging from 0 to 30 indicated normal Internet use, 31 to 49 indicated mild Internet addiction, 50 to 79 indicated moderate Internet addiction and scores ranging from 80 to 100 indicated severe Internet addiction (Young, 1998).

\subsection{General Health Questionnaire}

Goldberg DP et al., introduced the General Health Questionnaire (GHQ) for the determination of the presence or absence of psychological distress among respondents (Goldberg et al., 1978). General health questionnaire, versions-12 (GHQ-12) was used in this study. It contains 12 questions in which six of which are positively phrased 
Table 1. List of collected information.

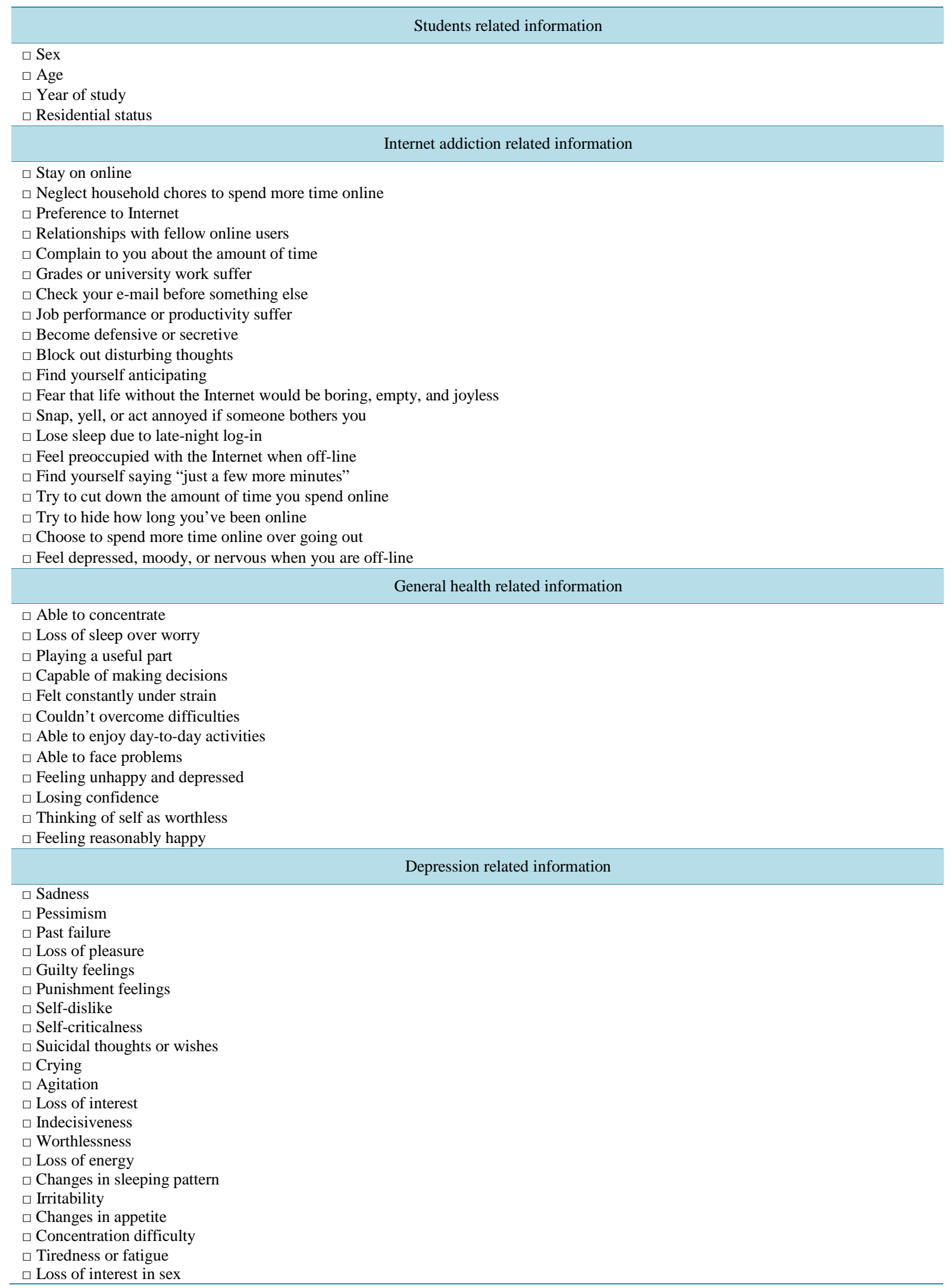


and six negatively phrased. Each item was rated on a four point scale includes; less than usual, no more than usual, rather more than usual, or much more than usual. The binary scoring method (0-0-1-1) was used for this study whereby the two least symptomatic answers scored 0 and the two most symptomatic answers scored 1 . So the obtainable scores ranged from 0 to 12 in which a score of 1 and above indicates a greater degree of psychological distress (Goldberg et al., 1978).

\subsection{Beck Depression Inventory}

Beck Depression Inventory, second edition (BDI-2) developed by Beck et al., was used for the determination of depression and its severity among respondents (Beck, Steer, \& Brown, 1996). It contains 21 questions, each answer being scored on a scale value of 0 to 3 . The obtainable scores ranged from 0 to 63 in which higher total scores indicated more severe depressive symptoms. Scores ranging from 0 to 13 indicated minimal depression, 14 to 19 indicated mild depression, 20 to 28 indicated moderate depression and scores ranging from 29 to 63 indicated severe depression (Beck, Steer, \& Brown, 1996).

\subsection{Statistical Analysis}

Data were collected and the results were finally compiled and presented. Chi-square tests of goodness of fit was performed to find relationships between variables. SPSS 15.0 (Chicago, IL, USA) and Microsoft Excel 2010 (Roselle, IL, USA) was used for the statistical and graphical evaluations. The results were considered as statistically significant at $P<0.05$.

\subsection{Scope for Error}

Since the study was based on the answers provided by the students and their prescriptions, so there was no scope for error unless they provided misinformation.

\subsection{Ethical Considerations}

The study protocol was approved by the ethics committee of the Department of Pharmacy, Southeast University, Dhaka, Bangladesh. The study was conducted in accordance with the ethical standards laid down in the 1964 Declaration of Helsinki.

\section{Results}

Among 475 students, 56\% (266) were male and 44\% (209) were female. The age group of the $41.5 \%$ (197) students were 18 - 21 years, followed by 58.5\% (278) in the age group between $22-25$ years. The students were in various years of study ranging from first to fourth (i.e., final) years; in which $26.7 \%$ (127) were in $1^{\text {st }}$ year, $22.7 \%$ (108) were in $2^{\text {nd }}$ year, $22.5 \%$ (107) were in $3^{\text {rd }}$ year and $28 \%$ (133) were in $4^{\text {th }}$ year student. The majority of the students, $71.2 \%$ (338) lived without family. Detailed participant related information is given in Table 2.

Table 2. Socio-demographic profile of the students.

\begin{tabular}{|c|c|c|c|}
\hline \multicolumn{2}{|c|}{ Variables } & \multirow{2}{*}{$\begin{array}{c}\mathrm{n} \\
266\end{array}$} & \multirow{2}{*}{\begin{tabular}{|c|}
$\%$ \\
56
\end{tabular}} \\
\hline Sex & Male & & \\
\hline & Female & 209 & 44 \\
\hline \multirow[t]{2}{*}{ Age (year) } & $18-21$ & 197 & 41.5 \\
\hline & $22-25$ & 278 & 58.5 \\
\hline \multirow[t]{4}{*}{ Year of study } & $1^{\text {st }}$ & 127 & 26.7 \\
\hline & $2^{\text {nd }}$ & 108 & 22.7 \\
\hline & $3^{\text {rd }}$ & 107 & 22.5 \\
\hline & $4^{\text {th }}$ & 133 & 28 \\
\hline \multirow[t]{2}{*}{ Residential status } & With family & 137 & 28.8 \\
\hline & Without family & 338 & 71.2 \\
\hline
\end{tabular}


The outcomes of Internet addiction test is shown in Table 3 with respect to sex in which $20.7 \%$ (55) male and 7.7\% (16) female students were affected by mild Internet addition. 27.1\% (72) male and 33.9\% (71) female students were moderately addicted by Internet and severe addiction was seen among 47.7\% (127) male and 44.5\% (93) female students. The association between Internet addiction and sex was significant at $P<0.001$. In the age group 18 - 21 years, 36.5\% (72) students were affected by severe addiction and $41 \%$ (114) in the age between 22 - 25 years. From $1^{\text {st }}$ year students, 37\% (47) had severe addiction and among $2^{\text {nd }}$ year students, severe addiction was realized for $34.3 \%$ (37) students. In case of $3^{\text {rd }}$ year students, $47.7 \%$ (51) possessed severe addiction, but for $4^{\text {th }}$ year students severe addiction was reported for $51.1 \%$ (68) students. The relationship between Internet addiction and year of the study was significant at $P<0.001$. Among students who lived with family $26.3 \%$ (36) had severe addiction. For students who lived without family, 30.2\% (102) were moderately addicted and severe addiction was shown for $47.9 \%$ (162) students. The link between Internet addiction and residential status was significant at $P<0.001$.

The results of psychological distress are given in Table 4. Psychological distress was reported among 29.7\% (79) male and 32.5\% (68) female students and remaining 70.3\% (187) male and 67.5\% (141) female students did not possess any distress. In the age group 18 - 21 years, 28.4\% (56) had psychological distress and for age group 22 - 25 years, 83\% (29.9) had psychological distress. Among $1^{\text {st }}$ year students, $24.4 \%$ (31) had psychological distress followed by $35.2 \%$ (38) in $2^{\text {nd }}$ year, afterward $25.2 \%(27)$ in $3^{\text {rd }}$ year and $34.6 \%(46)$ in $4^{\text {th }}$ year. Psychological distress was reported for $29.9 \%$ (41) students who lived with family and $37.9 \%$ (128) students who lived without family.

Table 3. Internet addiction relative to demographic characteristics of the students.

\begin{tabular}{|c|c|c|c|c|c|c|}
\hline \multirow{2}{*}{\multicolumn{2}{|c|}{ Parameters }} & \multicolumn{4}{|c|}{ Internet addiction, n (\%) } & \multirow{4}{*}{$\begin{array}{c}\chi^{2}(P) \text { values } \\
27.286(0.00000513)^{* * * *}\end{array}$} \\
\hline & & \multirow{3}{*}{$\begin{array}{l}\text { Normal } \\
12(4.5) \\
29(13.9)\end{array}$} & \multirow{3}{*}{$\begin{array}{c}\text { Mild } \\
55(20.7) \\
16(7.7)\end{array}$} & \multirow{3}{*}{$\begin{array}{l}\text { Moderate } \\
72(27.1) \\
71(33.9)\end{array}$} & \multirow{2}{*}{$\begin{array}{c}\text { Severe } \\
127(47.7)\end{array}$} & \\
\hline Sex & Male & & & & & \\
\hline & Female & & & & $93(44.5)$ & \\
\hline \multirow[t]{2}{*}{ Age (year) } & $18-21$ & $36(18.3)$ & $32(16.2)$ & 57 (28.9) & $72(36.5)$ & \multirow{2}{*}{$6.056(0.10891726)$} \\
\hline & $22-25$ & 39 (14.0) & $29(10.4)$ & $96(34.5)$ & $114(41.0)$ & \\
\hline \multirow[t]{4}{*}{ Year of study } & $1^{\mathrm{st}}$ & $21(16.5)$ & $36(28.3)$ & $23(18.1)$ & $47(37.0)$ & \multirow{4}{*}{$31.669(0.00022713)^{* * *}$} \\
\hline & $2^{\text {nd }}$ & $6(5.6)$ & $21(19.4)$ & $44(40.7)$ & 37 (34.3) & \\
\hline & $3^{\text {rd }}$ & $12(11.2)$ & $18(16.8)$ & $26(24.3)$ & $51(47.7)$ & \\
\hline & $4^{\text {th }}$ & $9(6.8)$ & $24(18.0)$ & $32(24.1)$ & $68(51.1)$ & \\
\hline \multirow{2}{*}{$\begin{array}{l}\text { Residential } \\
\text { status }\end{array}$} & With family & $16(11.7)$ & $32(23.3)$ & $53(38.7)$ & $36(26.3)$ & \multirow{2}{*}{$21.524(0.00008193)^{* * *}$} \\
\hline & Without family & $17(5.0)$ & 57 (16.9) & $102(30.2)$ & 162 (47.9) & \\
\hline
\end{tabular}

${ }^{* * *} P<0.001$ significant.

Table 4. Psychological distress relative to demographic characteristics of the students.

\begin{tabular}{|c|c|c|c|c|}
\hline \multirow{2}{*}{\multicolumn{2}{|c|}{ Parameters }} & \multicolumn{2}{|c|}{ Psychological distress, n (\%) } & \multirow{2}{*}{$\chi^{2}(P)$ values } \\
\hline & & \multirow{2}{*}{$\begin{array}{c}\text { Present } \\
79 \text { (29.7) }\end{array}$} & \multirow{2}{*}{$\begin{array}{c}\text { Absent } \\
187(70.3)\end{array}$} & \\
\hline Sex & Male & & & \multirow{2}{*}{$0.441(0.50664019)$} \\
\hline & Female & $68(32.5)$ & $141(67.5)$ & \\
\hline \multirow[t]{2}{*}{ Age (year) } & $18-21$ & $56(28.4)$ & $141(71.6)$ & \multirow{2}{*}{$0.114(0.73563535)$} \\
\hline & $22-25$ & $83(29.9)$ & $195(70.1)$ & \\
\hline \multirow[t]{4}{*}{ Year of study } & $1^{\text {st }}$ & $31(24.4)$ & $96(75.6)$ & \multirow{4}{*}{$5.772(0.12324545)$} \\
\hline & $2^{\text {nd }}$ & $38(35.2)$ & $70(64.8)$ & \\
\hline & $3^{\text {rd }}$ & $27(25.2)$ & $80(74.8)$ & \\
\hline & $4^{\text {th }}$ & $46(34.6)$ & $87(65.4)$ & \\
\hline \multirow[t]{2}{*}{ Residential status } & With family & 41 (29.9) & $96(70.1)$ & \multirow{2}{*}{$2.683(0.1014245)$} \\
\hline & Without family & $128(37.9)$ & $210(62.1)$ & \\
\hline
\end{tabular}


Table 5 represents the results of psychological depression. In this study, with respect to sex, $44.7 \%$ (119) male and $41.6 \%$ (87) female students were affected by severe psychological depression. In the age group 18 - 21 years, 36\% (71) had moderate depression and in the age group 22 - 25 years, severe depression was reported for $39.2 \%$ (109) students. $40.2 \%$ (51) $1^{\text {st }}$ year students were affected by severe depression after that $38.9 \%(42)$ in $2^{\text {nd }}$ year, followed by $40.2 \%(43)$ in $3^{\text {rd }}$ year and $55.6 \%(74)$ in $4^{\text {th }}$ year students. The relationship between psychological depression and year of study was significant at $P<0.05$. According to residential status, students who lived without family, 46\% (63) had moderate depression and in case of students who lived without family, moderate depression was reported for 26.9\% (91) and 52.9\% (179) had severe depression. The bond between psychological depression and sex was significant at $P<0.001$.

\section{Discussion}

The Internet is making the world smaller by making information more accessible to all and creating connections with different people around the world (Howe, 2016). However, it has also attracted many people to spend more time on the Internet, so that it becomes the center of their lives and causing neurological difficulties, psychological disorders and social complications (Griffiths, 2005; Shaffer et al., 2004). The younger generation is more prone to Internet addiction as a means of communicating, learning and seeking new challenges (Gordon, Juang, \& Syed, 2007). This is the first study showing prevalence of Internet addiction and its correlation with psychological distress and depression among undergraduate university students in Bangladesh.

The socio-demographic profile of the students shows that the prevalence of Internet addiction and its pathogenicity to psychological distress and depression was greater in male that female students. In addition to this 22 -25 years aged students who lived without family in $4^{\text {th }}$ year of study had greater Internet addiction as well as psychological distress and depression among 475 students of this study.

The prevalence of Internet addiction, psychological distress and depression varied among the students. In this study out of 475 students, $47.7 \%$ male and $44.5 \%$ female students were in the range of severe Internet addiction, then $27.1 \%$ male and $33.9 \%$ female students were in the range of moderate addiction, whereas $20.7 \%$ male and $7.7 \%$ female students were in the range of mild addiction. Young to adult every age people use the Internet, especially university students use the Internet for the preparation of the assignment, presentation, intern paper, reports etc. As well as to obtain current information the role of the Internet is unavoidable. However, the Internet assists university students in their academic endeavors, but it may also decrease the academic performance of students in fact, it is very easy for them to get addicted to the Internet (Greenhow, Robelia, \& Hughes, 2009; Katz, 2010). Due to excessive use of some site on the Internet these include web surfing, social media, pornography, freelancing, dating and video games that has been reported to be characterized by anxiety, agitation, headache, backache, weight gain or loss, blurred vision, dry eyes, sleep disturbance, depression, poor academic

Table 5. Psychological depression relative to demographic characteristics of the students.

\begin{tabular}{|c|c|c|c|c|c|c|}
\hline \multirow{2}{*}{\multicolumn{2}{|c|}{ Parameters }} & \multicolumn{4}{|c|}{ Psychological depression, n (\%) } & \multirow{2}{*}{$\chi^{2}(P)$ values } \\
\hline & & \multirow{2}{*}{$\begin{array}{l}\text { Normal } \\
14(5.3)\end{array}$} & \multirow{2}{*}{$\begin{array}{c}\text { Mild } \\
49(18.4)\end{array}$} & \multirow{2}{*}{$\begin{array}{l}\text { Moderate } \\
84(31.6)\end{array}$} & \multirow{2}{*}{$\begin{array}{c}\text { Severe } \\
119(44.7)\end{array}$} & \\
\hline Sex & Male & & & & & \multirow{2}{*}{$4.083(0.25263998)$} \\
\hline \multirow{3}{*}{ Age (year) } & Female & $21(10.0)$ & 35 (16.7) & $66(31.6)$ & $87(41.6)$ & \\
\hline & $18-21$ & $24(12.2)$ & 39 (19.8) & $71(36.0)$ & $63(32)$ & \multirow{2}{*}{3.179 (0.36484171) } \\
\hline & $22-25$ & 36 (12.9) & $46(16.5)$ & $87(31.3)$ & $109(39.2)$ & \\
\hline \multirow[t]{4}{*}{ Year of study } & $1^{\mathrm{st}}$ & $17(13.4)$ & $32(25.2)$ & $27(21.6)$ & $51(40.2)$ & \multirow{4}{*}{$17.143(0.04652314)^{*}$} \\
\hline & $2^{\text {nd }}$ & $9(8.3)$ & $24(22.2)$ & 33 (30.6) & 42 (38.9) & \\
\hline & $3^{\text {rd }}$ & $11(10.3)$ & $19(17.8)$ & 34 (31.8) & $43(40.2)$ & \\
\hline & $4^{\text {th }}$ & $7(5.3)$ & $23(17.3)$ & 29 (21.8) & $74(55.6)$ & \\
\hline \multirow{2}{*}{$\begin{array}{l}\text { Residential } \\
\text { status }\end{array}$} & With family & $12(8.8)$ & 26 (18.9) & $63(46.0)$ & $36(26.3)$ & \multirow{2}{*}{$29.705(0.00000159)^{* * *}$} \\
\hline & Without family & $16(4.7)$ & $52(15.4)$ & $91(26.9)$ & 179 (52.9) & \\
\hline
\end{tabular}

${ }^{*} P<0.05,{ }^{* * *} P<0.001$ significant. 
performance, carpal tunnel syndrome etc. (Wetterneck et al., 2012; Wise, Kim, \& Kim, 2010; Baird, 2010). Furthermore, $29.7 \%$ (79) male and 32.5\% (68) female students were found to be psychologically distressed. Severe psychological depression was reported among $44.7 \%$ (119) male and $41.6 \%$ (87) female students. This form of finding was in line with previous reports which have predicted many psychological problems arising from Internet addiction by university students (Weiser, 2000). Gnisci et al., stated that male college students were more addicted to the Internet than the female students (Gnisci et al., 2011).

The age of the students in this study ranged from 18 - 25 years. Severe Internet addiction 41\% (114) was reported in the age group 22 - 25 years, whereas moderate addiction was 34.5\% (96) and mild addiction was $10.4 \%$ (29). In the age group 18 - 21 years, 36.5\% (72), 28.9\% (57) and 16.2\% (32) students had severe, moderate and mild addiction respectively. Like Internet addiction, psychological distress was also maximum, $29.9 \%$ (83) in the age group 22 - 25 years. Stress is highly connected with depression. It is well known that depression appears after a stressful event (Monroe \& Reid, 2010). In this study severe psychological depression of this aforementioned aged (22 - 25 years) group was 39.2\% (109) and moderate depression was reported for 31.3\% (87) students whereas mild depression was reported for only $16.5 \%$ (46) students. A previous study revealed high levels of Internet addiction and psychological distress in young adolescents than adult adolescents (Okwaraji et al., 2015a).

From $1^{\text {st }}$ to $4^{\text {th }}$ year students severe Internet addiction was reported among $4^{\text {th }}$ year students than remaining year students, which was $51.1 \%$ (68) consequently psychological stress was $34.6 \%$ (46) and severe depression was $55.6 \%$ (74). This is may be as a result of preparing them for final year examinations and this may make them stay more on the Internet in the process of searching for study materials to help them write up their assignments as well as prepare very well for their job life. During this period they may tend to become addicted to the Internet more than other undergraduates who are not in their final years (Okwaraji et al., 2015b). Moderate Internet addiction was reported among $2^{\text {nd }}$ year students, which was $40.7 \%(44)$ than $1^{\text {st }}$ and $3^{\text {rd }}$ year students. Addition to Internet lead to psychological problems in this study greater number of $2^{\text {nd }}$ year students, $35.2 \%$ (38) had psychological distress than $1^{\text {st }}$ and $3^{\text {rd }}$ year students. This is not astonishing because young students are more at risk of becoming addicted to the Internet than older students due to the availability of free time, lack of monitoring by parents or caregivers and as a way of getting away from tough university routines. Okwaraji et al., showed that final year university undergraduates were at higher risk of developing Internet addiction and depression (Ozgul et al., 2013; Shaw \& Gant, 2002).

Regarding the residential status significant difference was noticed for Internet addiction, psychological distress and depression among students. In this study, 26.3\% (36) students lived with family were severely Internet addicted, then 29.9\% (41) had psychological distress and 26.3\% (36) had severe psychological depression. On the other hand, students who lived without family had more addicting behavioral than students lived with family. In this study, 47.9\% (162) students lived without family had severe Internet addiction, but $37.9 \%$ (128) had psychological distress and 52.9\% (179) had severe depression. Family plays an important role in the growth of student life (Christensen, 2013). The finding of this study suggests that Internet addiction and its psychological effect among students lived without family are probably due to lack of family bonding or lack of family care, aloneness and adjusting them with virtual life (Young, 2004).

\section{Conclusion}

The study exposed that the more addicted the students are to the Internet the more they develop psychological distress and depression. This is an alarming statistic that needs to be addressed as soon as possible. By considering the current fact of Internet addiction and psychological problems among undergraduate students as noticed in this study, there is prerequisite for parents and caregivers to monitor the Internet use and activity of the students. For students who are gradually addicted to the Internet or already addicted to the Internet, there is compulsory to screen them for proper counseling; mainly psycho education can be given to prevent the students from developing the Internet addiction and psychological problems. Furthermore, the government may take necessary action to regulate the Internet usage by students for the greater benefit of the nation.

\section{Limitation}

The present study was conducted in five universities of Bangladesh. It would be best if we could accomplish this study in numerous universities all over the country. 


\section{Acknowledgements}

The authors wish to thank the Department of Pharmacy, Southeast University, Dhaka, Bangladesh for providing research facilities.

\section{Ethical Approval}

The study protocol was approved by the ethics committee of the Department of Pharmacy, Southeast University, Dhaka, Bangladesh. The study was conducted in accordance with the ethical standards laid down in the 1964 Declaration of Helsinki.

\section{Author's Contributions}

This work was carried out in collaboration among all authors. MSU designed the study, wrote the protocol, managed the analyses of the study and prepared the draft of the manuscript. AAM managed the literature searches. AAM, MAI and MN collected data and complied results. MA and MSS performed statistical and graphical evaluations. MSA reviewed the scientific contents of the manuscript. All the authors read and approved the final manuscript.

\section{Conflict of Interests}

The authors proclaim that they have no conflict of interests.

\section{References}

Anonymous (2016a). Internet Addiction Disorder. https://en.wikipedia.org/wiki/Internet addiction disorder\#cite note-Beard and Wolf-95

Anonymous (2016b). Internet World Stats: Usage and Population Statistics. http://www.Internetworldstats.com/asia/bd.htm

Baird, C. (2010). How Much Internet Gaming Is Too Much. Journal of Addictions Nursing, 21, 52-53. http://dx.doi.org/10.3109/10884601003625688

Beard, K. W. (2005). Internet Addiction: A Review of Current Assessment Techniques and Potential Assessment Questions. Cyber Psychology \& Behavior, 8, 7-14. http://dx.doi.org/10.1089/cpb.2005.8.7

Beck, A. T., Steer, R. A., \& Brown, G. K. (1996). Manual for the Beck Depression Inventory-II. San Antonio: Psychological Corporation.

Block, J. J. (2008). Issues for DSM-V: Internet Addiction. American Journal of Psychiatry, 165, 306-307. http://dx.doi.org/10.1176/appi.ajp.2007.07101556

Cash, H., Rae, C. D., Steel, A. H., \& Winkler, A. (2012). Internet Addiction: A Brief Summary of Research and Practice. Current Psychiatry Reviews, 8, 292-298. http://dx.doi.org/10.2174/157340012803520513

Christensen, J. (2013). The Family's Role in a Child's Development. http://mom.me/kids/5258-familys-role-childs-development/

Echeburua, E., \& de Corral, P. (2010). Addiction to New Technologies and to Online Social Networking in Young People: A New Challenge. Adicciones, 22, 91-95.

Eisen, S., Lin, N., Lyons, M., Scherrer, J., Griffith, K., True, W. et al. (1998). Familial Influences on Gambling Behavior: An Analysis of 3359 Twin Pairs. Addiction, 93, 1375-1384. http://dx.doi.org/10.1046/j.1360-0443.1998.93913758.x

Gnisci, A., Perugini, M., Pedone, R., \& Conza, A. D. (2011). Construct Validation of the Use, Abuse and Dependence on the Internet Inventory. Computers in Human Behavior, 27, 240-247. http://dx.doi.org/10.1016/j.chb.2010.08.002

Goldberg, D. P. et al. (1978). Manual of the General Health Questionnaire. England: NFER Publishing.

Gordon, C. F., Juang, L. P., \& Syed, M. (2007). Internet Use and Well-Being among College Students: Beyond Frequency of Use. Journal of College Student Development, 48, 674-688. http://dx.doi.org/10.1353/csd.2007.0065

Grant, J. E., Brewer, J. A., \& Potenza, M. N. (2006). The Neurobiology of Substance and Behavioral Addictions. CNS Spectrums, 11, 924-930. http://dx.doi.org/10.1017/S109285290001511X

Greenhow, C., Robelia, B., \& Hughes, J. (2009). Learning, Teaching, and Scholarship in a Digital Age: Web 2.0 and Classroom Research: What Path Should We Take Now? Educational Researcher, 38, 233-245. http://dx.doi.org/10.3102/0013189X09336671

Griffiths, M. D. (2005). A “Components” Model of Addiction within a Biopsychosocial Framework. Journal of Substance 
Use, 10, 191-197. http://dx.doi.org/10.1080/14659890500114359

Griffiths, M. D. (2013). Social Networking Addiction: Emerging Themes and Issues. Journal of Addiction Research \& Therapy, 4, e118. http://dx.doi.org/10.4172/2155-6105.1000e118

Ha, J. H., Kim, S. Y., Bae, S. C., Bae, S., Kim, H., Sim, M. et al. (2007). Depression and Internet Addiction in Adolescents. Psychopathology, 40, 424-430. http://dx.doi.org/10.1159/000107426

Ho, R. C., Zhang M. W., Tsang T. Y., Toh, A. H., Pan, F., Lu, Y. et al. (2014). The Association between Internet Addiction and Psychiatric Co-Morbidity: A Meta-Analysis. BMC Psychiatry, 14, 183. http://dx.doi.org/10.1186/1471-244X-14-183

Howe, W. (2016). A Brief History of the Internet. http://www.walthowe.com/navnet/history.html

Jones, S. (2002). The Internet Goes to College: How Students Are Living in the Future with Today's Technology. http://eric.ed.gov/?id=ED472669

Kandell, J. J. (1998). Internet Addiction on Campus: The Vulnerability of College Students. CyberPsychology \& Behavior, 1, 11-17. http://dx.doi.org/10.1089/cpb.1998.1.11

Katz, R. (2010). Scholars, Scholarship, and the Scholarly Enterprise in the Digital Age. Educause Review, 45, 44-56.

Kim, K., Ryu, E., Chon, M. Y., Yeun, E. J., Choi, S. Y., Seo, J. S. et al. (2006). Internet Addiction in Korean Adolescents and its Relation to Depression and Suicidal Ideation: A Questionnaire Survey. International Journal of Nursing Studies, 43, 185-192. http://dx.doi.org/10.1016/j.ijnurstu.2005.02.005

Koo, H. J., \& Kwon, J. H. (2014). Risk and Protective Factors of Internet Addiction: A Meta-Analysis of Empirical Studies in Korea. Yonsei Medical Journal, 55, 1691-1711. http://dx.doi.org/10.3349/ymj.2014.55.6.1691

Kratzer, S., \& Hegerl, U. (2008). Is "Internet Addiction” a Disorder of Its Own? A Study on Subjects with Excessive Internet Use. Psychiatrische Praxis, 35, 80-83. http://dx.doi.org/10.1055/s-2007-970888

Kuss, D. J., \& Griffiths, M. D. (2011). Online Social Networking and Addiction-A Review of the Psychological Literature. International Journal of Environmental Research and Public Health, 8, 3528-3552. http://dx.doi.org/10.3390/ijerph8093528

Lee, S. B., Lee, K. K., Paik, K. C., Kim, H. W., \& Shin, S. K. (2001). Relationship between Internet Addiction and Anxiety, Depression, and Self Efficacy in Middle and High School Students. Journal of Korean Neuropsychiatric Association, 40, 1174-1184.

Leung, L., \& Lee, P. S. N. (2012). Internet Addiction Symptoms, and Internet Activities on Academic Performance. Social Science Computer Review, 30, 403-418. http://dx.doi.org/10.1177/0894439311435217

Monroe, S., \& Reid, M. W. (2010). Life Stress and Major Depression. Perspectives on Psychological Science, 5, 716-743.

Morris, K. (2009). Looking at Computer Use from Another Perspective. http://ww2.valdosta.edu/ bceditone/ENGL\%201102.htm

Mosher, D. (2011). High Wired: Does Addictive Internet Use Restructure the Brain? http://www.scientificamerican.com/article/does-addictive-Internet-use-restructure-brain/

Niemz, K., Griffiths, M., \& Banyard, P. (2006). Prevalence of Pathological Internet Use among University Students and Correlations with Self-Esteem, the General Health Questionnaire (GHQ), and Disinhibition. CyberPsychology \& Behavior, 11, 480-483.

Okwaraji, F. E., Aguwa, E. N., Onyebueke, G. C., \& Shiweobi-Eze, C. (2015a). Assessment of Internet Addiction and Depression in a Sample of Nigerian University Undergraduates. International Neuropsychiatric Disease Journal, 4, $114-122$. http://dx.doi.org/10.9734/INDJ/2015/19096

Okwaraji, F. E., Aguwa, E. N., Onyebueke, G. C., Arinze-Onyia, S. U., \& Shiweobi-Eze, C. (2015b). Gender, Age and Class in School Differences in Internet Addiction and Psychological Distress among Adolescents in a Nigerian Urban City. International Neuropsychiatric Disease Journal, 4, 123-131. http://dx.doi.org/10.9734/INDJ/2015/18933

Ozgul, O., Ozlem, O., Alaettin, U., \& Ozalp, S. S. (2013). Evaluation of Internet Addiction and Depression among University Students. Procedia-Social and Behavioral Sciences, 82, 445-454. http://dx.doi.org/10.1016/j.sbspro.2013.06.291

Pies, R. (2009). Should DSM-V Designate “Internet Addiction” a Mental Disorder? Psychiatry (Edgmont), 6, 31-37.

Poli, R., \& Agrimi, E. (2012). Internet Addiction Disorder: Prevalence in an Italian Student Population. Nordic Journal of Psychiatry, 66, 55-59. http://dx.doi.org/10.3109/08039488.2011.605169

Ryan, K. (2014). Internet Addiction Affects 6\% of People Worldwide. http://www.liebertpub.com/global/pressrelease/Internet-addiction-affects-6-of-people-worldwide/1576/

Shaffer, H. J., LaPlante, D. A., LaBrie, R. A., Kidman, R. C., Donato, A. N., \& Stanton, M. V. (2004). Toward a Syndrome Model of Addiction: Multiple Expressions, Common Etiology. Harvard Review of Psychiatry, 12, 367-374. http://dx.doi.org/10.1080/10673220490905705

Shaw, L. H., \& Gant, L. M. (2002). In Defence of the Internet: The Relationship between Internet Communication and De- 
pression, Loneliness, Self Esteem and Perceived Social Support. CyberPsychology \& Behavior, 5, 157-171. http://dx.doi.org/10.1089/109493102753770552

Soule, L., Shell, W., \& Kleen, B. (2003). Exploring Internet Addiction: Demographic Characteristics and Stereo Types of Heavy Internet Users. Journal of Computer Information Systems, 44, 64-73.

Wallace, P. (2014). Internet Addiction Disorder and Youth: There Are Growing Concerns about Compulsive Online Activity and That This Could Impede Students’ Performance and Social Lives. EMBO Reports, 15, 12-16. http://dx.doi.org/10.1002/embr.201338222

Weinstein, A., \& Lejoyeux, M. (2010). Internet Addiction or Excessive Internet Use. The American Journal of Drug and Alcohol Abuse, 36, 277-283. http://dx.doi.org/10.3109/00952990.2010.491880

Weiser, E. B. (2000). Gender Differences in Internet Use Patterns and Internet Application Preferences: A Two Sample Comparison. CyberPsychology \& Behavior, 3, 167-178. http://dx.doi.org/10.1089/109493100316012

Wetterneck, C. T., Burgess, A. J., Short, M. B., Smith, A. H., \& Cervantes, M. E. (2012). The Role of Sexual Compulsivity, Impulsivity, and Experiential Avoidance in Internet Pornography Use. Psychological Record, 62, 3-17.

Wise, K., Kim, H. J., \& Kim, J. (2010). Erratum: The Effect of Searching vs. Surfing on Cognitive and Emotional Responses to Online News. Journal of Media Psychology, Theories, Methods, and Applications, 22, 45. http://dx.doi.org/10.1027/1864-1105/a000013

Woollaston, V. (2014). Are You Addicted to the Internet? Study Finds 6\% of People Around the World-That's a Staggering 182 Million-Now Struggle to Stay Offline. http://www.dailymail.co.uk/sciencetech/article-2880344/Are-addicted-Internet-Study-finds-6-people-world-s-staggering-1 82-million-struggle-stay-offline.html\#ixzz42HohL4Qg

Young, K. (2009). Issues for Internet Addiction as a New Diagnosis in the DSM-V. Washington: American Psychological Association. http://dx.doi.org/10.1037/e625212009-001

Young, K. S. (1998). Internet Addiction: The Emergence of a New Clinical Disorder. CyberPsychology \& Behavior, 1, 237244. http://dx.doi.org/10.1089/cpb.1998.1.237

Young, K. S. (2004). Internet Addiction: A New Clinical Phenomenon and Its Consequences. American Behavioral Scientist, 48, 402-415. http://dx.doi.org/10.1177/0002764204270278

Young, K. S., \& de Abreu, C. N. (2011). Internet Addiction: A Handbook and Guide to Evaluation and Treatment. Hoboken, NJ: John Wiley \& Sons Inc.

Young, K. S., \& Rogers, R. C. (1998). The Relationship between Depression and Internet Addiction. CyberPsychology \& Behavior, 1, 25-28. http://dx.doi.org/10.1089/cpb.1998.1.25

Yuan, K., Qin, W., Wang, G., Zeng, F., Zhao, L., Yang, X. et al. (2011) Microstructure Abnormalities in Adolescents with Internet Addiction Disorder. PLOS ONE, 6, e20708. http://dx.doi.org/10.1371/journal.pone.0020708

Zaman, S. N., \& Rowshon, A. (2011) Internet Usage by the Students of Faculty of Arts, University of Dhaka (Bangladesh). Pearl: A Journal of Library and Information Science, 5, 14-22. 


\section{Abbreviations}

IAT: Internet Addiction Test;

GHQ: General Health Questionnaire;

BDI: Beck Depression Inventory;

IAD: Internet addiction disorder;

ADHD: Attention deficit hyperactivity disorder;

CIAR: Center for Internet Addiction Recovery.

Submit or recommend next manuscript to SCIRP and we will provide best service for you:

Accepting pre-submission inquiries through Email, Facebook, Linkedin, Twitter, etc A wide selection of journals (inclusive of 9 subjects, more than 200 journals)

Providing a 24-hour high-quality service

User-friendly online submission system

Fair and swift peer-review system

Efficient typesetting and proofreading procedure

Display of the result of downloads and visits, as well as the number of cited articles

Maximum dissemination of your research work

Submit your manuscript at: http://papersubmission.scirp.org/ 